\title{
AMYLASE RELEASE FROM PAROTID GLANDS OF HYPOTHYROID RATS I. ALTERED RESPONSIVENESS TO ADRENERGIC AGENTS
}

\author{
Masakatsu TACHIBANA and Yasumichi HAGINO \\ Department of Pharmacology, Nagoya University School of Medicine, \\ Showa-ku. Nagoya 466, Japan
}

Accepted July 7, 1982

\begin{abstract}
Effects of adrenergic agents on $\alpha$ - and $\beta$-adrenergic receptors of parotid glands from hypothyroid rats were compared with those of euthyroid rats. The sensitivity for amylase release from parotid slices to adrenergic agents did not change even in hypothyroid status because ED50 values for amylase release in both groups were approx. the same: $7 \times 10^{-8} \mathrm{M}$ for isoproterenol, $4-6 \times 10^{-6} \mathrm{M}$ for phenylephrine and $10^{-5} \mathrm{M}$ for methoxamine. However, the responsiveness of the tissue to those agents which was determined as the maximal amylase release was significantly higher in hypothyroid status than in the euthyroid status. The maximal increases in amylase release in euthyroid and hypothyroid rats were approx. $7.4 \%$ and $10.0 \%$ of the total in isoproterenol, $3.9 \%$ and $7.4 \%$ of the total in phenylephrine and $1.3 \%$ and $2.7 \%$ of the total in methoxamine. respectively. The effect of dibutyryl cyclic AMP mimicked that of isoproterenol, and the responsiveness of the tissue in this case was much higher in the hypothyroid rats than in the euthyroid rats. Furthermore, $10 \mathrm{mM}$ tolbutamide, which completely inhibited the activity of cyclic AMP-dependent protein kinase, blocked isoproterenol-induced amylase release by $66.5 \%$ in euthyroid rats, against only $36.3 \%$ in hypothyroid rats. These results strongly suggest that the regulation mediated through $\beta$ adrenergic receptors plays a major role in amylase release from rat parotid glands even under hypothyroid status, and the step following cyclic AMP synthesis might, at least in some way, be involved in this regulation.
\end{abstract}

It is well known that amylase release from rat parotid glands is mediated through a number of receptor mechanisms including $\alpha$ and $\beta$-adrenergic, cholinergic and peptidergic systems (1-3). Recent studies have indicated that amylase release from the rat parotid gland is provoked mainly via activation of $\beta_{1}$ adrenergic receptors $(2,4,5)$. Additionally, this enzyme release is modulated by various factors such as denervation, decentralization. and some chemical compounds (6-8).

In earlier studies, the present authors have reported that the sensitivity of the $\beta$-adrenergic receptor to isoproterenol decreased in the heart of hypothyroid rats, whereas that of the $\alpha$-adrenergic receptors to phenylephrine increased $(9,10)$. Moreover, the $\beta$-adrenergic receptors in the heart were also classified as a $\beta_{1}$-subtype by Lands et al. $(11,12)$.

Therefore, the present study was designed to examine the extent of amylase release from the parotid glands of hypothyroid rats by stimulation of an $\alpha$-or $\beta$-adrenergic agonist and attempted to obtain further information on 
the properties of adrenergic receptors in rat parotid glands.

\section{MATERIALS AND METHODS}

Materials: L-Isoproterenal hydrochloride and $L$-phenylephrine hydrochloride were obtained from Sigma. L-methoxamine hydrochloride was kindly provided by the Nippon Shinyaku Co., L-propranolol hydrochloride was from the Sumitomo Chemical Co., phentolamine mesylate from CIBA-Geigy. and dibutyryl cyclic AMP from Boehringer. Tolbutamide $\mathrm{Na}$ was the product of the Yamanouchi Pharmaceutical Co. Other chemicals were obtained from commercial sources. Drug concentrations refer to the final concentration in the tissue bath.

Treatment of the animals: Male Wistar rats, weighing 170 to $250 \mathrm{~g}$, were made hypothyroidic by feeding them on a $0.15 \%$ propylthiouracil diet for more than 12 weeks. Serum concentrations of L-3,5,3'triiodothyronine and $L$-thyroxine were markedly decreased in these rats as described previously (13). Euthyroid rats received a standard laboratory chow and water ad libitum. Animals were fasted for 16-20 hr prior to use, anesthetized by injection of sodium pentobarbital $(40 \mathrm{mg} / \mathrm{kg}$ body weight, i.p.), and killed by exsanguination via the abdominal aorta. Parotid glands were quickly removed and placed in Krebs-Ringer bicarbonate buffer ( $\mathrm{pH}$ 7.4) containing $10 \mathrm{mM}$ glucose and $5 \mathrm{mM} \beta$-hydroxybutyrate with $\mathrm{O}_{2} / \mathrm{CO}_{2}(95: 5 \mathrm{v} / \mathrm{v})$ as the gas phase.

Assay for amylase release: The glands were trimmed of fat, blood vessels, and connective tissue and cut into slices weighing about $2 \mathrm{mg}$ : approx. 14-17 $\mathrm{mg}$ of the slices were weighed and preincubated for $20 \mathrm{~min}$ in $5 \mathrm{ml}$ medium at $37^{\circ} \mathrm{C}$. Incubation glass vials were designed for continuous equilibration of the medium with an $\mathrm{O}_{2} / \mathrm{CO}_{2}$ gas mixture throughout the experiment according to Danielsson (14). After preincubation, the medium was removed with a pipette, the fragments were rinsed once with fresh buffer at a temperature of $37^{\circ} \mathrm{C}$, and then $5 \mathrm{ml}$ of fresh, prewarmed. gassed incubation buffer was added to the tissue fragments.

Agonists alone or in combination with antagonists were added to each vial, and the reaction was started. Control incubations without drugs were included in each experiment. For the secretory responses, tissues were incubated for $15 \mathrm{~min}$ with agonists alone and in the combination with antagonists which had been added $10 \mathrm{~min}$ prior to the addition of agonists. When the effect of tolbutamide on the amylase release was examined, tissues were preincubated for 30 $\min$ in Krebs-Ringer bicarbonate buffer containing $10 \mathrm{mM}$ tolbutamide and then isoproterenol was added. In the case of dibutyryl cyclic AMP, tissues were incubated for $60 \mathrm{~min}$. After incubation, the tissues were homogenized in $0.05 \mathrm{M}$ phosphate buffer $(\mathrm{pH}$ 6.9) with a glass-Teflon homogenizer. Incubation media and homogenates were appropriately diluted with $0.05 \mathrm{M}$ phosphate buffer ( $\mathrm{pH}$ 6.9) and assayed for amylase by the method of Ceska et al. (15). The total amount of amylase was determined by summation of the amount in the medium and that remaining in the tissue at the end of the incubation. The percent of the total amylase which was released into the incubation medium was then calculated.

Statistical analyses for significance were carried out using the Student's $t$-test.

\section{RESULTS}

Tissue amylase contents and basal amylase release from parotid glands of normal and hypothyroid rats: As shown in Table 1, it was found that the amylase content in the parotid glands of hypothyroid rats was $18.41 \pm 1.29 \mathrm{lU} / \mathrm{mg}$ of wet tissue, and this value was approx. one half of the normal value. Moreover, the non-stimulated amylase 
Table 1. Effect of hypothyroid status on parotid amylase content and its release during incubation

\begin{tabular}{lcc}
\hline $\begin{array}{l}\text { Amylase } \\
\text { Content }\end{array}$ & $\begin{array}{c}\text { Euthyroid } \\
(n=23)\end{array}$ & $\begin{array}{c}\text { Hypothyroid } \\
(\mathrm{n}=24)\end{array}$ \\
\hline $\begin{array}{l}\text { Tissue } \\
\text { (IU/mg tissue) }\end{array}$ & $40.12 \pm 1.90$ & $18.41 \pm 1.29^{*}$ \\
$\begin{array}{l}\text { Medium } \\
\text { (IU/mg tissue } / 15 \mathrm{~min})\end{array}$ & $0.90 \pm 0.05$ & $0.19 \pm 0.02^{*}$ \\
\hline
\end{tabular}

The parotid slices were preincubated in Krebs-Ringer bicarbonate $(\mathrm{pH} \mathrm{7.4)}$ for 20 min. After changing the medium, the slices were incubated for $15 \mathrm{~min}$. Values are the means $\pm S$. E. for (n) determinations. $P<0.01$ compared to the euthyroid rats.

release from the glands of the hypothyroid rats was $0.19 \pm 0.02 \mathrm{lU} / \mathrm{mg}$ during the $15 \mathrm{~min}$ incubation, and this value was about one fifth that of the normal parotid glands during the $15 \mathrm{~min}$ incubation. Total protein content in the tissue was $130.8 \pm 4.6 \mu \mathrm{g} / \mathrm{mg}$ tissue in the normal rats and $114.2 \pm 9.8 \mu \mathrm{g} / \mathrm{mg}$ tissue in the hypothyroid rats. These results suggested that contents of specific enzyme proteins decreased in the hypothyroid status.

Effects of $\alpha$ - and $\boldsymbol{\beta}$-adrenergic agonists on amylase release: As shown in Fig. 1, amylase release was increased dose-dependently by isoproterenol in both normal and hypothyroid rats. At a concentration of $10^{-7} \mathrm{M}$ isoproterenol, amylase release from the hypothyroid parotid glands was slightly higher than that of the normal and reached $10.0 \%$ of the total at $10^{-6} \mathrm{M}$. On the other hand, in euthyroid rats, the maximal amylase release was approx. $7.4 \%$ of the total at $10^{-6} \mathrm{M}$ isoproterenol. However, the ED50 value for amylase release was approx. $7 \times 10^{-8} \mathrm{M}$ in both normal and hypothyroid rats. Effects of phenylephrine on amylase release was less effective than that of isoproterenol. An increased amylase release was observed at a concentration of $10^{-6} \mathrm{M}$ in both euthyroid and hypothyroid rats and reached the maximum at approx. $3 \times 10^{-5} \mathrm{M}$. The maximal response to phenylephrine was slightly smaller than that with isoproterenol: $3.9 \%$ of the total in euthyroid and $7.4 \%$ in hypothyroid rats.

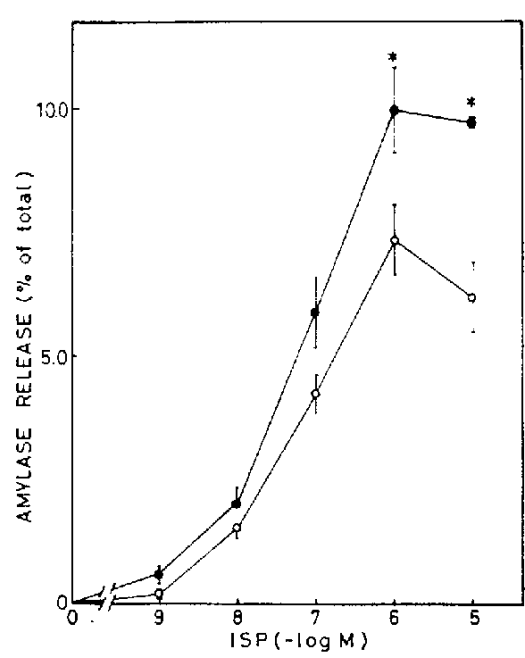

Fig. 1. Effect of isoproterenol (ISP) on amylase release from parotid glands of euthyroid and hypothyroid rats. Tissue slices were preincubated for $20 \mathrm{~min}$ at $37^{\circ} \mathrm{C}$ and transferred to new medium. After addition of isoproterenol, incubations were continued for $15 \mathrm{~min}$. Values are the means $\pm S . E$. of $8-9$ experiments for each point. Asterisks indicate a significant level of $\mathrm{P}<0.05$ as compared with the euthyroid rats. Euthyroid $(\mathrm{O}-\mathrm{O})$ : Hypothyroid ( $-\mathrm{O})$.

ED50 values for amylase release were $4 \times 10^{-6}$ $M$ in the euthyroid rats and $6 \times 10^{-6} \mathrm{M}$ in the hypothyroid rats (Fig. 2). Figure 3 shows that methoxamine also released amylase dosedependently from both the euthyroid and the hypothyroid rat gland, although the maximal values were $1.3 \%$ of the total in the euthyroid rats and $2.7 \%$ in the hypothyroid rats. The ED50 value for amylase release was approx. 
$10^{-5} \mathrm{M}$ in both groups. These results showed that methoxamine was the least potent and

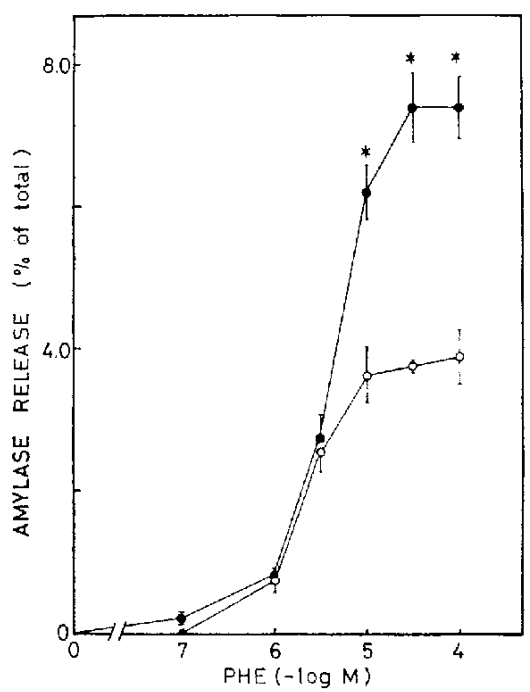

Fig. 2. Effect of phenylephrine (PHE) on amylase release from parotid glands of euthyroid and hypothyroid rats. Values are the means \pm S.E. of 6-15 experiments. Asterisks indicate a significant level of $P<0.001$ as compared with the euthyroid rats. The conditions for amylase release are as described for Fig. 1.

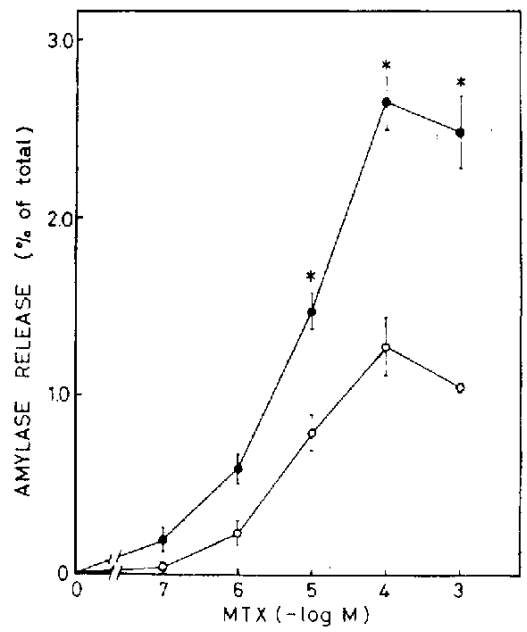

Fig. 3. Effect of methoxamine (MTX) on amylase release from parotid glands of euthyroid and hypothyroid rats. Values are the means $\pm S$.E. of 6-8 experiments. Asterisks indicate a significant level of $P<0.001$ as compared with the euthyroid rats. The conditions for amylase release are as described for Fig. 1. isoproterenol the most potent agonist among the drugs tested for stimulation of amylase release in this study.

Effects of adrenergic blocking agents on the stimulation of amylase release by adrenergic agonists: Effects of propranolol and phentolamine on isoproterenol-induced amylase release are shown in Fig. 4. Isoproterenol-induced amylase release was not inhibited by addition of phentolamine either in the euthyroid or hypothyroid rats. On the other hand, $10^{-7} \mathrm{M}$ propranolol completely inhibited of the effect of $10^{-8} \mathrm{M}$ isoproterenol in both groups. However, the same concentration of propranolol inhibited dose-dependently the amylase release induced by $10^{-7} \mathrm{M}$ or $10^{-6} \mathrm{M}$ isoproterenol: approx. $80 \%$ inhibition in euthyroid and $70 \%$ inhibition in hypothyroid rats at $10^{-7} \mathrm{M}$ isoproterenol and approx. $60 \%$ inhibition in the euthyroid and

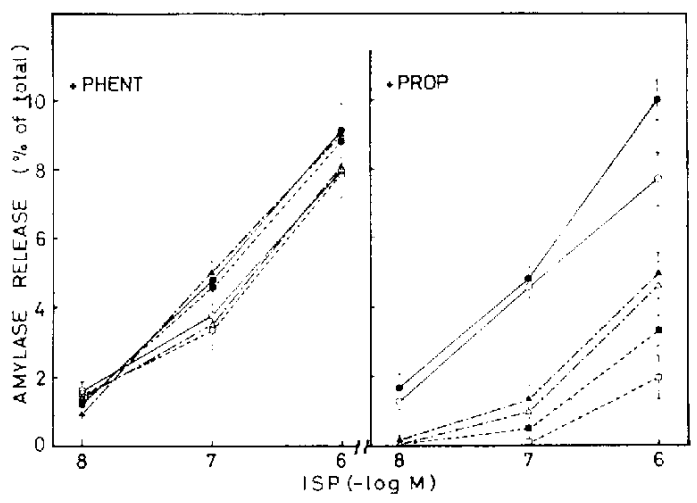

Fig. 4. Effects of phentolamine (PHENT) and propranolol (PROP) on isoproterenol (ISP)induced amylase release from parotid glands of euthyroid and hypothyroid rats. Tissue slices were preincubated for $20 \mathrm{~min}$ at $37^{\circ} \mathrm{C}$, and then the medium was changed. The slices were incubated with phentolamine or propranolol for $10 \mathrm{~min}$ before addition of isoproterenol. After the latter, incubations were continued for 15 min. Values are the means $\pm S$.E. of 4-5 experiments. +PHENT: with phentolamine, +PROP: with propranolol. Euthyroid: control $\mathrm{O}-\mathrm{O}$. with $10^{-7} \mathrm{M}$ arrtagonist $\triangle-\cdots \Delta$, with $10^{-6} \mathrm{M}$ antagonist $\square$....... Hypothyroid: control - with $10^{-7} \mathrm{M}$ antagonist $\mathbf{A}-\mathbf{-} \mathbf{\Delta}$. with $10^{-6} \mathrm{M}$ antagonist 
$50 \%$ inhibition in the hypothyroid at $10^{-6} \mathrm{M}$ isoproterenol. Amylase release induced by $10^{-8}$ or $10^{-7} \mathrm{M}$ isoproterenol was completely inhibited by the addition of $10^{-6} \mathrm{M}$ propranolol in the normal rat, and the effect of $10^{-6} \mathrm{M}$ isoproterenol was inhibited approx. by $75 \%$ of the control with the same concentration of propranolol. On the other hand. the amylase release with $10^{-8} \mathrm{M}$ isoproterenol was completely blocked by $10^{-6} \mathrm{M}$ propranolol in hypothyroid rats, whereas effects of $10^{-7} \mathrm{M}$ and $10^{-6} \mathrm{M}$ isoproterenol was inhibited approx. by $90 \%$ and $70 \%$ of the control, respectively.

Similarly, as shown in Fig. 5, phenylephrine-induced amylase release was concentration-dependently inhibited by phentolamine. Thus, effects of $10^{-6}$ and $3 \times 10^{-6} \mathrm{M}$ phenylephrine were completely inhibited by $10^{-7} \mathrm{M}$ phentolamine. whereas that of $10^{-5}$ $M$ phenylephrine on normal parotid glands was inhibited by about $25 \%$ of the control at $10^{-7} \mathrm{M}$ phentolamine and by approx. $50 \%$ at $10^{-6} \mathrm{M}$ phentolamine. In hypothyroid rats, $10^{-7} \mathrm{M}$ phentolamine showed nearly complete inhibition on the amylase release induced by $10^{-6} \mathrm{M}$ or $3 \times 10^{-6} \mathrm{M}$ phenylephrine, while that with $10^{-5} \mathrm{M}$ phenyl-

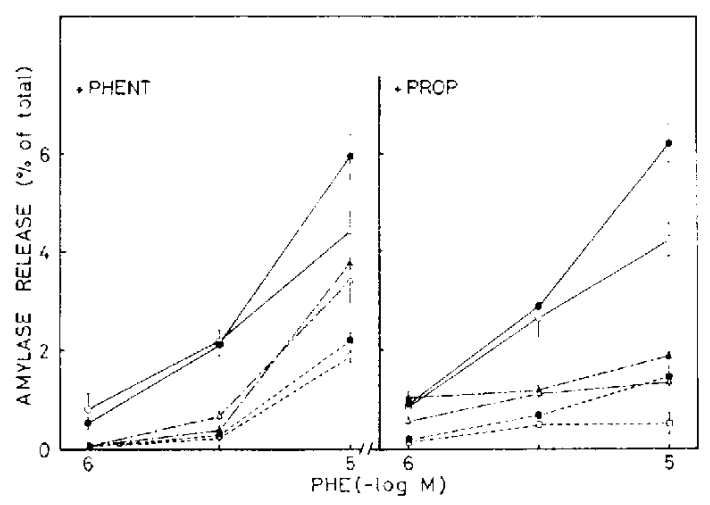

Fig. 5. Effects of phentolamine (PHENT) and propranolol (PROP) on phenylephrine (PHE)induced amylase release from parotid glands of euthyroid and hypothyroid rats. Values are the means \pm S.E. of $4-5$ experiments. The conditions are as described for Fig. 4. ephrine was inhibited approx. by $35 \%$ of the control. Moreover, $10^{-6} \mathrm{M}$ phentolamine also completely blocked the effects of $10^{-6} \mathrm{M}$ and $3 \times 10^{-6} \mathrm{M}$ phenylephrine and by approx. $65 \%$ of the control at $10^{-5} \mathrm{M}$ phenylephrine. Propranolol at the concentration of $10^{-6} \mathrm{M}$ practically completely inhibited the increased amylase release induced by phenylephrine at the concentration of $10^{-5} \mathrm{M}$ in euthyroid rats. but in the hypothyroid rats, a slight increase of the amylase release was stilf observed by phenylephrine combined with propranolol.

Methoxamine-induced amylase release was completely inhibited by the addition of $10^{-6} \mathrm{M}$ or $10^{-7} \mathrm{M}$ phentolamine in the euthyroid: whereas in hypothyroid rats, $10^{-7}$ $M$ phentolamine only partially blocked the increase in amylase release by methoxamine. Propranolol did not show any effect on amylase release induced by methoxamine (Fig. 6).

Effect of dibutyryl cyclic AMP on amylase release: In this experiment, the parotid glands were incubated for $60 \mathrm{~min}$ after the addition of dibutyryl cyclic AMP. As shown in Fig. 7. dibutyryl cyclic AMP stimulated amylase release in both normal and hypothyroid rats. The amylase release from the glands increased

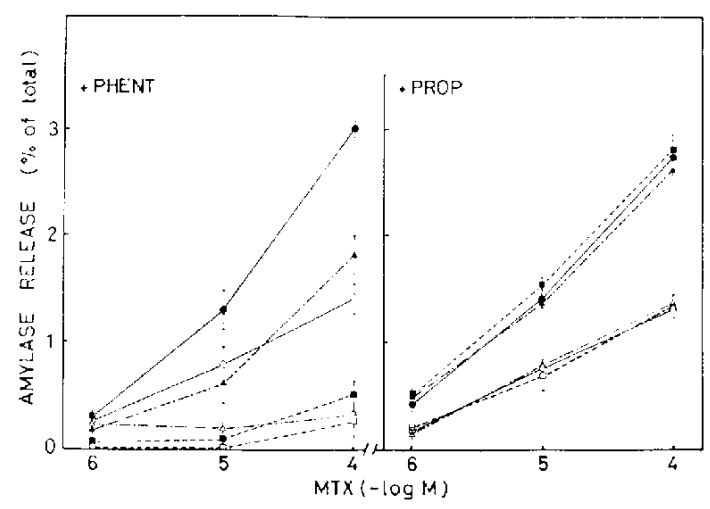

Fig. 6. Effects of phentolamine (PHENT) and propranolol (PROP) on methoxamine (MTX)induced amylase release from parotid glands of euthyroid and hypothyroid rats. Values are the means \pm S.E. of 4-5 experiments. The conditions are as described for Fig. 4. 
dose-dependently and reached a maximum at $10^{-3} \mathrm{M}$ in both normal and hypothyroid rats. In hypothyroid rats, amylase release

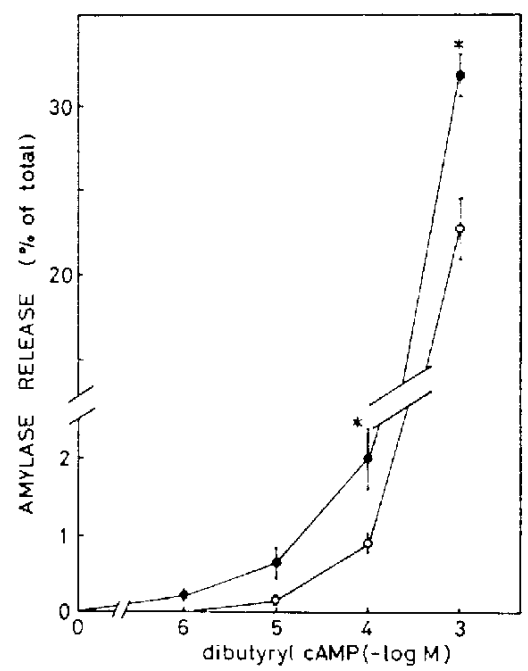

Fig. 7. Effect of dibutyryl cyclic AMP (dibutyryl CAMP) on amylase release from parotid glands of euthyroid and hypothyroid rats. Tissue slices were preincubated for $20 \mathrm{~min}$, and then the medium was changed. After the addition of the indicated amount of dibutyryl cyclic AMP, the slices were incubated for $60 \mathrm{~min}$. Values are the means \pm S.E. of $3-5$ experiments. Asterisks indicate a significant level of $P<0.05$ as compared with the euthyroid rats. Euthyroid (O-O). Hypothyroid significantly increased at $10^{-4} \mathrm{M}$ as compared with that of the normal.

Effect of tolbutamide on isoproterenolinduced amylase release: Tolbutamide inhibited the activity of cyclic AMP-dependent protein kinase in adipose tissue (16) and parotid gland (17). Kanamori et al, also suggested that $\beta$-adrenergic-stimulated amylase release from parotid gland was mediated through the activation of cyclic AMP-dependent protein kinase (17). As shown in Table 2, tolbutamide showed only a slight increase in amylase release in both groups. However, $10 \mathrm{mM}$ tolbutamide reduced isoproterenol-induced amylase release from approx. $10 \%$ to $7.5 \%$ in both groups: and owing to a difference in the amount of basal amylase release. the net percent increase of amylase release was decreased from $7.54 \%$ to $2.71 \%$ in the euthyroid rats and from $9.42 \%$ to $6.0 \%$ in the hypothyroid rats. Accordingly, the percent inhibition with tolbutamide was $66.5 \%$ in the normal rats and $36.3 \%$ in the hypothyroid rats.

\section{DISCUSSION}

The present study investigated the effects of $\alpha$ - and $\beta$-adrenergic agonists on amylase

Table 2. Effect of tolbutamide on isoproterenol-induced amylase release

\begin{tabular}{lcc}
\hline & \multicolumn{2}{c}{$\%$ of total amylase released } \\
\hline None & Euthyroid & Hypothyroid \\
Tolbutamide & $3.07 \pm 0.62$ & $0.70 \pm 0.06^{*}$ \\
Isoproterenol & $4.83 \pm 0.50$ & $1.62 \pm 0.01^{*}$ \\
Isoproterenol Tolbutamide & $10.61 \pm 0.69$ & $10.12 \pm 0.32$ \\
\% Inhibition & $7.54 \pm 0.26$ & $7.62 \pm 0.57$ \\
\hline
\end{tabular}

Parotid slices were preincubated in Krebs-Ringer bicarbonate $(\mathrm{pH} \mathrm{7.4)}$ or Krebs-Ringer bicarbonate containing $10 \mathrm{mM}$ tolbutamide (TB) $\left(\mathrm{pH} \mathrm{7.4)}\right.$ for $30 \mathrm{~min}$ at $37^{\circ} \mathrm{C}$. At the end of the preincubation, $10^{-6} \mathrm{M}$ isoproterenol (ISP) was added, followed by incubation for 15 min. Controls (none and TB, without ISP) were incubated in each experiment. Percent of TB inhibition of ISP-induced amylase release was calculated as follows:

$$
\% \text { inhibition }=\left[1-\frac{(I S P+T B)-T B}{\text { ISP-None }}\right] \times 100
$$

$* P<0.01$ compared to the euthyroid rats. 
release from parotid glands of hypothyroid rats. It is well known that in euthyroid rats, $\beta$-adrenergic receptors play the major role in the regulation of amylase release, and $\alpha$ adrenergic receptors play a minor role (18). Moreover, the effect of $\beta$-adrenergic stimulation on amylase release is mediated by cyclic AMP as a second messenger $(2,19)$. whereas $\alpha$-adrenergic stimulated amylase release required calcium $(1,2,20)$. It is also established that the functions of adrenergic receptors are modulated by thyroid hormones: thyroxine potentiates epinephrine-induced amylase release in the parotid gland (21), and a decreased sensitivity of $\beta$-adrenergic receptors and an increased sensitivity of $\alpha$ adrenergic receptors in the atria of hypothyroid rats $(9,10,22)$ appears as well as a decreased sensitivity of $\beta$-adrenergic receptors in fat cell and erythrocyte in hypothyroid rats $(23,24)$.

In the present study, the amount of tissue amylase in hypothyroid rats was reduced by about $50 \%$ that in euthyroid rats (Table 1 ). However, total protein content in the tissue was essentially the same in the two groups. and when the values in Table 1 were calculated on the basis of $\mathrm{mg}$ of protein. the tissue amylase content was $306.7 \pm 14.5 \mathrm{lU} /$ $\mathrm{mg}$ protein in the euthyroid rats and $161.1 \pm$ $11.4 \mathrm{U} / \mathrm{mg}$ protein in the hypothyroid rats. Amylase concentration in the medium was $6.88 \mathrm{l} / \mathrm{mg}$ protein $/ 15 \mathrm{~min}$ in the euthyroid group and $1.66 \mathrm{l} / \mathrm{mg}$ protein $/ 15 \mathrm{~min}$ in the hypothyroid group, respectively. In these circumstances, amylase release from hypothyroid parotid slices was induced by addition of isoproterenol and significantly increased at concentrations higher than $10^{-7} \mathrm{M}$ as compared to that in normal parotid glands (Fig. 1). The sensitivity of adrenergic receptors to adrenergic agonists did not change in the hypothyroid status: ED50 values for amylase release were about $7 \times 10^{-8} \mathrm{M}$ with isoproterenol, $6 \times 10^{-6} \mathrm{M}$ with phenylephrine. and $10^{-5} \mathrm{M}$ with methoxamine. These values were essentially the same in the two groups (Figs. 1, 2 and 3) and also consistent with those of others $(1,25)$. However, the maximal amylase release was 1.5 - to 2 -fold higher in hypothyroid rats than in euthyroid ones. Stimulation of $\beta$-adrenergic receptors with isoproterenol resulted in an amylase release several times greater than with $\alpha$ adrenergic receptors by methoxamine in euthyroid rats. This prevailing property of $\beta$ adrenergic receptors on amylase release still remained in hypothyroid rats.

Propranolol blocked the stimulatory effect of isoproterenol in a dose-dependent manner. but phentolamine had no such effect (Fig. 4). The effect of phenylephrine on amylase release was also inhibited essentially in the same manner as with isoproterenol (Fig. 5). On the other hand, the effect of methoxamine on amylase release was completely blocked in euthyroid rats by $10^{-7}$ or $10^{-6} \mathrm{M}$ phentolamine. In hypothyroid rats, $10^{-6} \mathrm{M}$ phentolamine also completely blocked amylase release induced by methoxamine, while $10^{-7}$ $M$ phentolamine only partially blocked the increase in amylase release by $10^{-4} \mathrm{M}$ methoxamine. Propranolol had no effect on the increased amylase release induced by methoxamine (Fig. 6).

These results suggested that even in hypothyroid status, amylase release from parotid glands was regulated both by $\alpha$ - and $\beta$-adrenergic receptors and still mainly mediated by $\beta$-adrenergic receptor systems. This speculation was further confirmed by the experiments of dibutyryl cyclic AMP and tolbutamide (Fig. 7 and Table 2). Addition of dibutyryl cyclic AMP into the media stimulated amylase release from the parotid glands, and the rate of amylase release was higher in the hypothyroid rats than that in the euthyroid ones. Moreover, $10 \mathrm{mM}$ tolbutamide, which was known as an inhibitor of cyclic AMP-dependent protein 
kinase, markedly inhibited amylase release from the glands of euthyroid rats, but only slightly inhibited it in hypothyroid rats. The effect of tolbutamide on amylase release from euthyroid rat glands was essentially the same as that reported by Kanamori et al. (17). These results strongly suggested the possibility that the increased response to $\beta$ adrenergic stimulation in hypothyroid rats might account, at least in part, for the increased rate of phosphorylation of endogenous protein by cyclic AMP-dependent protein kinase. This problem will be discussed in the following paper

Kunos proposed that interconversion of $\alpha$ - and $\beta$-adrenergic receptors might occur under the conditions of tissue metabolic changes such as altered thyroid hormone levels or temperature (22). However, Malbon et al. (23) and Garcia-Sainz and Fain (26) observed in fat cells that the sensitivity of $\beta$-adrenergic receptors decreased in hypothyroid rats, whereas that of $\alpha$-adrenergic receptors remained unchanged. In the present study, the sensitivity of $\alpha$-and $\beta$-adrenergic receptors did not change in terms of amylase release as a parameter. On the other hand, the responsiveness of both adrenergic receptors increased in hypothyroid rats with elevation of the maximal release. These results suggest that the properties of adrenergic receptors in parotid gland were the same as those of fat cells, and the interconversion of $\alpha$ - and $\beta$ adrenergic receptors did not occur in the parotid gland under hypothyroid status.

The present results indicate the possibility that adrenergic-induced amylase release from the parotid glands of hypothyroid rats is regulated by $\alpha$ - and $\beta$-adrenergic receptors, and the $\beta$-adrenergic receptor may play a major role. The release mediated through $\beta$ adrenergic receptors was regulated in part at the step following cyclic AMP synthesis.

\section{REFERENCES}

1) Leslie, B.A., Putney, J.W., Jr. and Sherman, J.M.: $\alpha$-Adrenergic, $\beta$-adrenergic and cholinergic mechanisms for amylase secretion by rat parotid gland in vitro. J. Physiol. (Lond.) 260 . $351-370(1976)$

2) Butcher, F.R., Goldman, J.A. and Nemerovski, M.: Effect of adrenergic agents on $\alpha$-amylase release and adenosine $3^{\prime}, 5^{\prime}$-monophosphate accumulation in rat parotid tissue slices. Biochim. Biophys. Acta 392, 82-94 (1975)

3) Butcher, F.R.: Regulation of exocytosis. In Biochemical Actions of Hormones. Edited by Litwack, G., Vol. 5, p. 53-99. Academic Press, New York (1978)

4) Au, D.K., Malbon, C.C. and Butcher, F.R.: Identification and characterization of $\hat{\beta}_{1}$ adrenergic receptors in rat parotid membranes. Biochim. Biophys. Acta 500, 361-371 (1977)

5) Carlsöö, B., Danielsson, A. and Henriksson, R.: Effects of a new selective $\beta_{1}$-adrenoceptor agonist on amylase secretion from the rat parotid gland. Br. J. Pharmacol, 62, 364-366 (1978)

6) Ekström, J.: Sensitization of the rat parotid gland to secretogogues following either parasympathetic denervation or sympathetic denervation or decentralization. Acta Physiol. Scand. 108, 253-261 (1980)

7) De Peusner, I C.W., Stefano, F.J.E. and Perec, S.I.: Effects of sympathectomy on the in vivo $\alpha$ and $\beta$-responses of the parotid gland. Naunyn Schmiedebergs Arch. Pharmacol. 308, 211-216 (1979)

8) De Peusner, I.C.W., Perec, C.J. and Stefano, F.J.E.: Effects of sympathectomy on the in vitro $\alpha$ and $\beta$-responses of the parotid gland. Naunyn Schmiedebergs Arch. Pharmacol. 308 , 217-221 (1979)

9) Nakashima, M., Maeda, K., Sekiya, A. and Hagino, Y.: Effect of hypothyroid status on myocardial responses to sympathomimetic drugs. Japan. J. Pharmacol. 21, 819-825 (1971)

10) Nakashima, M. and Hagino, Y.: Evidence for the existence of alpha adrenergic receptor in isolated rat atria. Japan. J. Pharmacol. 22, 227233 (1972)

11) Lands, A.M., Arnold, A., Mcauliff, J.P., Luduena, F.P. and Brown, T.G.: Differentiation of receptor systems activated by sympathomimetic amines. Nature 214, 597-598 (1967)

12) Lands, A.M., Luduena, F.P. and Buzzo, H.J.: Differentiation of receptors responsive to isoproterenol. Life Sci. 6, 2241-2249 (1967) 
13) Hagino, Y., Uematsu, T. and Tachibana, M.: Effects of phenylephrine and isoproterenol on the activity of cyclic AMP-dependent protein kinase of hypothyroid rat tissues. Japan. J. Pharmacol. 29, 889-898 (1979)

14) Danielsson, A.: Techniques for measuring amylase secretion from pieces of mouse pancreas. Anal. Biochem. 59, 220-234 (1974)

15) Ceska, M., Birath, K. and Brown, B.: A new and rapid method for the clinical determination of $\alpha$-amvlase activities in human serum and urine optimal conditions. Clin. Chim. Acta 26, 437444 (1969)

16) Wray, H.L. and Harris, A.W: Adenosine 3'.5'monophosphate-dependent protein kinase in adipose tissue. Inhibition by tolbutamide. Biochem. Biophys. Res. Commun. 53, 291-294 (1973)

17) Kanamori, T., Hayakawa, T. and Nagatsu, T.: Adenosine $3^{\prime} .5^{\prime}$-monophosphate-dependent protein kinase and amylase secretion from rat parotid gland. Biochem. Biophys. Res. Commun. 57, 394-398 (1974)

18) Jirakulsomchok, D. and Schneyer, C.A.: Effects on rat parotid amylase and $\mathrm{Ca}$ of $\alpha$-and $\beta$-adrenergic sympathetic stimulation. Am. J. Physiol. 236, E371-E385 (1979)

19) Bdolah, A. and Schramm, M.: Factors controlling the process of enzyme secretion by the rat parotid gland. Biochem. Biophys. Res. Commun. 8, 266-270 (1962)

20) Petersen, O.H., Ueda, N., Hall, R.A. and Gray, T.A.: The role of calcium in parotid amylase secretion evoked by excitation of cholinergic, $\alpha$ - and $\beta$-adrenergic receptors. Pflügers Arch. $372,231-237$ (1977)

21) Nelson, T.E. and Stouffer, J.E.: Thyroxine modulation of epinephrine stimulated secretion of rat parotid $\alpha$-amvlase. Biochem. Biophys. Res. Commun. 48, 480-485 (1972)

22) Kunos, G.: Thyroid hormone-dependent interconversion of myocardial $\alpha$ - and $\beta$-adrenoceptors in the rat. $\mathrm{Br}$. J. Pharmacol. 59, 177 $189(1977)$

23) Malbon, C.C., Moreno, F.J., Cabelli, R.J. and Fain, J.N.: Fat cell adenylate cyclase and $\beta$. adrenergic receptors in altered thyroid states. J. Biol. Chem. 253, 671-678 (1978)

24) Furukawa, H., Loeb, J.N. and Bilezikian, J.P. Beta-adrenergic receptors and isoproterenolstimulated potassium transport in erythrocytes from normal and hypothyroid turkeys. Quantitative relation between receptor occupancy and physiologic responsiveness. J. Clin. Invest. 66 , 1057-1064 (1980)

25) Baum, B.J., Freiberg, J.M., Ito, H., Roth, G.S. and Filburn, C.R.: $\beta$-Adrenergic regulation of protein phosphorylation and its relationship to exocrine secretion in dispersed rat parotid gland acinar cells. J. Biol. Chem. 256, 9731-9736 (1981)

26) Garcia-Sainz, J.A. and Fain, J.N.: Effect of adrenergic amines on phosphatidylinositol labeling and glycogen synthase activity in fat cells from euthyroid and hypothyroid rats. Mol. Pharmacol. 18, 72-77 (1980) 